\title{
The Role of Labor Unions in Corporate Transparency: Focusing on the Role of Governance in Auditor Change Process
}

\author{
Eun Jung Cho ${ }^{1}$, Ju Ryum Chung ${ }^{2, *}$ and Ho-Young Lee ${ }^{3}[$ \\ 1 Department of Taxation, Namseoul University, Chunan 31020, Korea; ejcho34@nsu.ac.kr \\ 2 School of Business Administration, University of Seoul, Seoul 02504, Korea \\ 3 School of Business, Yonsei University, Seoul 03722, Korea; hylee@yonsei.ac.kr \\ * Correspondence: jrchung0@uos.ac.kr; Tel.: +82-2-6490-2262
}

Received: 11 April 2019; Accepted: 1 May 2019; Published: 8 May 2019

check for updates

\begin{abstract}
This study investigates how the presence and power of labor unions are associated with auditor replacement, more specifically, external auditor tenure and the direction of auditor change. External auditor tenure and direction have been of great interest to stakeholders, as they are very likely associated with the financial reporting quality and corporate transparency, crucial factors for sustainable business. We are focusing on the role of the labor union, one of the key stakeholders involved in corporate governance and transparent operations, in external auditor selection processes. During the annual wage bargaining process, labor unions that rely on financial information face information asymmetry because financial statements are provided by the management. Therefore, labor unions have a high demand for independent and capable external auditors. This demand is likely to shorten auditor tenure and/or prompt changes to higher-quality auditors. Using a sample of 4568 firm-years listed in the Korean stock markets for the period of 2005 to 2008, we find evidence that the presence and power of labor unions significantly decrease external auditor tenure. We also find that the direction of auditor changes with the presence and power of labor unions is likely from non-industry specialist auditors to industry specialist auditors. This study contributes to the extant literature by extending the previous research on auditor selection and the governance role of labor unions.
\end{abstract}

Keywords: auditor switch; auditor tenure; labor union; audit quality

\section{Introduction}

Corporate transparency is an important factor in maintaining the sustainable market economy in which business can operate. Companies carry out various activities such as operations, investment, and finance to sustain the business. These business activities are reported as a form of financial statements. As market participants rely on financial information provided by firms, they demand effective monitoring associated with the quality of financial reporting. External auditors play the most important role in corporate monitoring by providing independent and professional assurance services for financial reporting (Rodgers et al. [1]). This service reduces the information asymmetry between the users and providers of financial information. Knowing that external auditors play a key role in reducing information asymmetry, labor unions, one of the most significant stakeholders of firms, are likely to demand high-quality audits. Prior studies have often emphasized the role of the board of directors, external auditors or corporate social responsibility on corporate transparency to ensure sustainability (Jin et al. [2], Islam [3], Dhaliwal et al. [4]). Prior studies have also provided evidence that unions play a role in improving the quality of financial reporting. However, very few studies 
have examined the role of unions in enhancing the effectiveness of the monitoring mechanism. In this paper, we examine whether labor unions enhance the effectiveness of the monitoring mechanism provided by external auditors. To be specific, we investigate whether the presence and strength of unions reduce auditor tenure and affects the direction of auditor change in the circumstances of the change of the auditor.

Labor unions play a significant role in representing employees' interest and protecting employees' rights. After labor unions officially obtained the right to represent employees under union acts (e.g., the National Labor Relations Act (NLRA) in 1935 in the United States and Trade Union Act in 1953 in Korea), the influence of unions over management has dramatically increased. Labor unions play an important role in firms' productivity and profitability. Additionally, labor unions create either positive or negative publicity about their firms during collective bargaining processes, which in turn can heavily affect firm value (In Korea, the Seoul Economy Daily reported that based on Motors Industry Association data, for the last 5 years, Hyundai Motors and Kia Motors lost 11,890 trillion won (USD 10,809 million with an exchange rate of 1100) due to under-production during union strikes [5] and thus sustainability (Connolly et al. [6]).

Politicians and regulators also regard labor unions as important because they are aware of the power labor unions have in influencing political interests (Kau and Rubin [7]; Box-Steffensmeier et al. [8]; Jansa and Hoyman [9]; Becher et al. [10]). As labor unions have become more influential over management, investors and other stakeholders have become more interested in labor unions' governance roles in monitoring management (Chyz et al. [11]; Choi and Bae [12]). Among the various governance mechanisms, this study examines the role of labor unions in external auditor changes-specifically, it examines the association between the presence/power of labor unions and external auditor tenure and the direction of external auditor changes.

The role of labor unions is to protect the rights of employees and demand improvements in benefits and wage increases based on the financial performance of their firms. For example, labor unions negotiate wages and employee benefits with management based on financial information. To demand a more favorable share and increase their bargaining power, labor unions require more information that is accurate and transparent (Kleiner and Bouillon [13]; Leung et al. [14]; Appelbaum and Hunter [15]). However, prior studies have reported that management has incentives to hide accurate information about resources and/or financial performance in order to obtain the upper hand in the process of negotiating wage contracts (Kleiner and Bouillon [13]; Hilary [16]; Bova [17]). Since companies have other stakeholders, such as shareholders, investors and financial analysts, managers may have incentives to provide favorable accounting results. Unlike other developed countries, however, the monitoring role of labor unions is much stronger in Korea due to the difference in a sociological and historical environment. Chung et al. [18] and Cheng et al. [19] both investigate the effect of unions in two different countries, Korea and the US, respectively, on the selection of a high-quality auditor, and they find conflicting results. We acknowledge that the difference in the results of the two studies can be attributable to differences in the environment of the two countries.

External auditors have professional knowledge and expertise in evaluating the effectiveness of accounting systems and internal control over financial reporting, which affect the quality of financial reporting. They enter at the last step of the financial reporting process, verifying whether financial statements are fairly prepared according to generally accepted accounting standards. As an independent outside governance mechanism, they are expected to play one of the most important roles as a financial information watchdog. When they find an error or a violation of standards, they discuss the problems with management in order to fix them. Labor unions expect high-quality external auditors to minimize the risk of inaccurate financial information and thus reduce the information asymmetry between them and management. In other words, labor unions that prefer to rely on financial statements audited by high-quality external auditors in the process of wage negotiation are highly likely to demand that management not use external auditors whose independence is questionable. 
Long external auditor tenure has received negative publicity during a series of corporate scandals (Blouin et al. [20]). As a long tenure is perceived as causing a loss of independence, the European Union and several Asian countries have started to implement mandatory auditor changes (Chen et al. [21]; Catanach and Walker [22]). An increase in audit quality when an auditor changes may also reflect the demand for high-quality auditors by labor unions. To minimize the risk of labor-management conflicts, management also has incentives to respond to this demand by switching from external auditors with long tenures to new auditors that are perceived as high quality.

While prior studies find evidence that board characteristics are associated with audit quality (O'Sullivan [23]; Carcello et al. [24]; Carcello and Neal [25]; Klein [26]) and the likelihood and/or direction of auditor change (Lee et al. [27]; Beasley and Petroni [28]), few studies focus on the role of labor unions in audit quality. Chung et al. [18] report that firms with labor unions are likely to have Big 4 auditors (Big4 auditors indicate the four biggest global audit firms. They are Deloitte, PricewaterhouseCoopers (PwC), Ernst and Young (EY), and KPMG. According to Audit Analytics Report in February 2017, Big4 auditors audit $99.4 \%$ of S and P 500 companies.). They also provide evidence that unionization is negatively (positively) associated with positive (negative) abnormal audit fees and abnormal audit hours, suggesting that departures from normal audit fees and hours in either direction impair audit quality. They suggest that labor unions affect the improvement of audit quality, but do not examine auditor replacement that affects tenure or the direction of auditor changes (There are cases where labor unions affect audit quality and auditor change decisions. For example, "The labor union of Hyundai Motors demanded management change external auditors since the auditor has audited their firm for a long time. The labor union raised a strong concern that a long tenure with an auditor decreases objectivity and the independence of the auditor. While the selection of external auditors is primarily management's decision, the motion must be seconded at the shareholders meeting. A representative of the labor union states that it has a collective agreement with management regarding auditor selection. The representative also states that the union will clearly demand that management change its external auditors after discussion with the employee stockholders association (Yonhap News, 24 December 2002)." Additionally, according to Bloomberg, the American Federation of Labor and Congress of Industrial Organizations (AFL-CIO) recommended that shareholders of Sprint Corporation oppose the selection of $\mathrm{E}$ and $\mathrm{Y}$ as the firm's new external auditor. AFL-CIO argues that $\mathrm{E}$ and $\mathrm{Y}$ has long provided tax consulting for top executives of Sprint. This may cause a conflict of interest in conducting financial statement audits (Blumberg, 23 April 2003).). Labor unions demand high-quality audits to ensure transparent and reliable financial information. An external auditor working for a long period of time for a specific client develops a close relationship with the client's management (Blouin et al. [20]). Additionally, economic bonding between management and the auditor increases as the tenure increases, which may, in turn, lower the audit quality (Carey and Simmett [29]; Davis et al. [30]; Dopuch et al. [31]). Thus, influential labor unions are likely to push firms to change their long-term external auditors in order to ensure auditor independence. This push will eventually reduce auditor tenure when labor unions play a significant monitoring role. If an auditor change occurs, labor unions are likely to influence their firms to select high-quality auditors. At the same time, when firms with influential labor unions change auditors, they are expected to appoint higher-quality auditors to signal high-quality financial information.

Korea provides an ideal setting for testing the effect of labor unions, as it has experienced severe labor disputes over time. Also, labor unions in Korea are extremely strong and have gained political influence (Jung [32]). Many Korean firms have experienced severe labor disputes over the past decades because of strong unions, causing huge losses (In Korea, most unions are affiliated with Minju or Hanguk federation. Labor White Paper of 2008 in Korea states that about 89 percent of unions are affiliated with these two federations. These two federations are very powerful and more influential than those in other countries. This powerful nature of labor unions in Korea may be attributed to the fact that the rapid democratization of Korean society after the sudden end of the military regime in the early $1990 \mathrm{~s}$. This democratization has empowered organized labor strongly increasing the 
effectiveness of their corporate monitoring role. Minju is known as more aggressive, while Hanguk is relatively less aggressive. About 87 percent of strikes are supported by Minju while 11 percent is by Hanguk around 2005-2008 (Labor White Paper of 2008). Labor disputes with management are also of great concerns among Chaebols, family-run business conglomerates in Korea. Labor unions have increased aggressiveness against these Chaebol firms.). As a result, developing good labor-management relations has been of great concern to firms to avoid labor disputes, and thus labor unions play a critical monitoring role (Chen et al. [33]; Choi and Bae [12]). Thus, firms are more likely to incorporate the demands of labor unions associated with auditor change that directly affect the information asymmetry between employees and management. The results indicate that the demands of labor unions for higher-quality external audits are considered when the auditor tenure is long and when firms change their auditors. Using 4568 firm-years listed on the Korea Stock Exchange, we find that the presence and power of labor unions decrease external auditor tenure. We also find that firms with labor unions, especially powerful labor unions, are more likely to change their auditors to industry specialists from non-industry specialists and from non-large audit firms to large audit firms. For the robustness test, we control for the characteristics of firms with unions or powerful unions using propensity score matching, and the results remain qualitatively the same.

This study contributes to the extant literature in several ways. First, it adds to the few extant studies on the monitoring role of labor unions. In particular, it is increasingly important to understand the monitoring role of labor unions because workers' rights and the role of employees as a major stakeholder group are increasingly important now more than ever before. Second, by empirically examining how the presence of labor unions and the strength of their influence are associated with auditor tenure and the direction of auditor changes, this study provides useful implications for investors and regulators by showing that the role of labor unions must be considered in their decision making. To the best of our knowledge, this research question has not yet been examined, mainly because of the lack of data availability. Third, our paper provides an explanation for how unions affect audit quality. A previous study (Chung et al. [18]) documented that companies with unions are more likely to have higher-quality auditors. Our paper provides additional evidence that unions may influence changes in auditors, which can improve auditor independence, leading to higher audit quality. Lastly, different from US studies, which estimate unionization by industry-level data due to data limitations (Hilary [16]; Chyz et al. [11]; Hsieh et al. [34]), this study provides comprehensive results on the impact of unions by using unique data available in Korea up to 2008, which includes firm-level union data (The influence of labor unions over management has increased over time in Korea. Thus, the inclusion of more recent data is likely to strengthen the conclusion of our study. The influence and power of labor unions have increased with the support of the government. For example, the Koreatimes (7 January 2019) indicated that "the nation's two umbrella labor organizations have strengthened the power and influence drastically thanks to current president's pro-labor policies and a sharp increase in the number of labor union".).

The paper proceeds as follows. In Section 2, we review the relevant literature and develop our hypotheses. In Section 3, we describe the research design and the sample selection process. In Section 4, we describe the empirical results, and Section 5 concludes the paper.

\section{Extant Literature and Hypothesis Development}

\subsection{Labor Unions and Financial Information}

The extant literature documents that labor unions want to receive more reliable information to function effectively, but managers are reluctant to provide such information transparently in order to gain an upper hand in wage negotiations and to limit the release of discretionary information (Hilary [16]; Chung et al. [35]). Hilary [16] finds that information asymmetry proxied as the bid-ask spread, probability of informed trading, trading volume and analyst coverage are positively related to organized labor. He argues that management has an incentive to hide information in order to obtain a 
better position in collective bargaining. Similarly, Chung et al. [18] provide evidence that managers tend to withhold good news and break bad news in order to increase their negotiating power over labor unions. Bova [17] shows that the management of firms with labor unions has an incentive to misstate mean consensus analyst earnings estimates in order to mitigate the wealth transfer from a firm's shareholders to unionized employees and to provide negative signals about a firm's future profitability.

In addition to affecting the discretionary information-providing behavior of management, unions affect the accounting practices of firms. For example, Leung et al. [14] examine the accounting conservatism of firms with unionized employees, and they find that firms with labor unions are more conservative in accounting. D'Souza et al. [36] investigate the discretionary SFAS 106 choices of non-regulated firms. They find that unionized firms immediately adopt SFAS 106, which results in losses in the current period but enables them to better position themselves in future collective bargaining by increasing their future profits.

Although a large stream of prior studies regarding unions have focused on a negative outlook of unions as rent-seekers and document a negative effect on firms' information quality and disclosure behavior, some studies found that unions play a positive role as monitoring organizations that limit the discretion of managers. For example, Chyz et al. [11] examine the impact of the labor union on firms' tax aggressiveness. They find a negative relation between firms' efforts to reduce taxes and union power; therefore, the stronger labor unions are, the less the managers try to reduce taxes. This relation occurs for one, or both, of two reasons: (1) unions provide better monitoring and therefore constrain managers' ability to invest in tax aggressiveness or (2) returns from tax avoidance acts are decreased as a result of the rent-seeking behavior of labor unions. In other words, unions have the incentive to monitor firms' accounting policies or systems in order to increase their bargaining power by acquiring more transparent financial information.

Chung et al. [18] examine whether unions affect the type of external auditor and audit scope. They find that a firm with a labor union is likely to choose a high-quality auditor, proxied as Big $\mathrm{N}$, and an industry specialist auditor. They also find that a stronger union is negatively associated with positive abnormal audit fees and abnormal audit hours. They suggest that labor unions demand high-quality audits and play a monitoring role to constrain management's opportunistic behavior.

Using US data, Cheng et al. [19] find conflicting results with Chung et al. [18]. They find that firms with labor unions are less likely to choose Big 4 or industry specialist auditors. They argue that managers want to lower the quality of audits in order to limit the information provided to unions. Regarding the relation between managers and unions, managers want to hide information, and unions always need more information. Therefore, firms may select low-quality auditors from the manager's perspective.

Like Chung et al. [18] and Cheng et al. [19], we investigate the relationship between unions and auditor selection. However, while they study the management decision of hiring a Big 4 auditor, we focus more on the union's active role in auditor change to obtain more reliable and independent accounting information. Specifically, we investigate whether the labor union affects auditor tenure if the duration with an incumbent auditor is not considered appropriate. In addition, we examine whether the union has an impact on auditor change, i.e., the direction in which the union affects the auditor selection process by analyzing the direction of auditor change. Compared to Chung et al. [18] and Cheng et al. [19], who examined all firms without considering auditor changes, our study examines the union's more detailed and specific role in improving external governance to ensure accounting quality and/or corporate transparency.

\subsection{Auditor Tenure and Audit Quality}

As regulators are very concerned with the negative effect of a long tenure with an incumbent auditor on auditor independence, many countries either have adopted (e.g., the European Union, Indonesia, Bangladesh, Costa Rica) or are considering adopting (e.g., Korea, Canada) mandatory auditor rotation (see https://www.complianceweek.com/blogs/global-glimpses/auditor-rotation-are- 
we-going-round-in-circles for discussion of regulatory bodies on mandatory rotation rule). The Korean government introduced a modified version of a mandatory auditor rotation rule effective in 2019 that requires auditor designation after six years of audit engagement (see http://www.newsis.com/view/ ?id=NISX20190130_0000546490\&cID=10401\&pID=10400 for the mandatory auditor designation rule). DeAngelo [37] determines audit quality as the joint probability that the auditor will find and report material misstatements. Finding a material misstatement is a function of the auditor's knowledge or technical expertise; from that perspective, auditor tenure has a positive effect on audit quality. However, the likelihood of reporting misstatements that are found during an audit is a function of auditor independence, and auditor's independence might deteriorate as tenure increases. Thus, the relation between audit quality and auditor tenure cannot clearly be determined. Although previous studies on auditor tenure have mostly been conducted based on practitioners' concern that auditor independence is impaired as the audit period increases, the results are inconsistent.

Some studies show that audit quality is higher with consecutive audits (Myers et al. [38]; Geiger and Raghunandan [39]; Johnson et al. [40]). Myers et al. [38] examine the relation between auditor tenure and audit quality measured by discretionary earnings management. The results reveal higher earnings quality with a longer auditor tenure, which means that extended auditor tenure constrains management decisions in reporting financial performance rather than impairing auditor independence. Geiger and Raghunandan [39] analyze 117 bankrupt firms from 1996 to 1998 whose audit opinions issued on financial statements immediately prior to bankruptcy differed according to auditor tenure. The analysis shows that the likelihood of an incorrect audit opinion is higher when auditor tenure is shorter; this suggests a positive relationship between auditor tenure and audit quality. Studies have also shown that auditor independence is impaired as auditor tenure increases, resulting in poor audit quality (Carey and Simmett [29]; Davis et al. [30]; Dopuch et al. [31]). Carey and Simnett [29] investigate the effect of audit partner tenure on audit quality using Australian data for the period before mandatory rotation system adoption. They use three measures of audit quality: the auditor's propensity to issue a going-concern audit opinion, abnormal working capital accruals, and just beating (missing) earnings benchmarks. They find that the longer the partner's audit period is extended, the less likely the issuance of a going-concern opinion and the more likely the firm just beats (meets) earnings benchmarks. These results indicate that audit quality deteriorates with longer audit partner tenure. Similarly, Davis et al. [30] find that the use of discretionary accruals to meet or beat earnings forecasts is increased in both the early and later years of auditor tenure in the pre-SOX period. However, they do not find a relation between auditor tenure and discretionary accruals in the post-SOX period. Kealey et al. [41], suggest that successor auditors perceive a longer tenure with a previous auditor as risky since the length of tenure may impair audit quality. In addition, Dopuch et al. [31] conduct an experimental study to investigate how mandatory rotation or retention of auditors may increase auditor independence. They find that auditor rotation requirements increase auditor independence compared to other regimes in which rotation is not imposed.

Despite the mixed results of these previous studies, major economic scandals such as Enron and Daewoo Shipbuilding and Marine Engineering Co. have been the result of audit failure caused by an impairment of auditor independence caused by ties between the auditor and the client as a result of the long tenure. Thus, a practical view still exists that longer auditor tenure impairs the independence of auditors. In this study, we want to determine whether unions, as a form of corporate governance, affect auditor tenure to prevent audit failure and enhance audit quality.

\subsection{Auditor Change and Governance Mechanism}

Companies change auditors for a variety of reasons, including accounting disagreements, fee disputes, and/or the issuance of a qualified audit opinion. Most studies focus on client-initiated auditor changes for opportunistic purposes, such as opinion shopping, and provide supportive findings (Smith [42]; Davidson et al. [43]; Francis et al. [44]). In this regard, an effective monitoring system can prevent frequent auditor changes. Robinson and Owens [45] investigate the association between audit 
committee characteristics and auditor changes and find that auditor changes are less likely if audit committee members are more independent, have more financial expertise, and have more firm-specific knowledge. From this perspective, auditor changes can be motivated by opportunistic incentives under ineffective governance mechanisms. Using 1574 sample firm-years of Korean data in the period of 2000-2003, Lee et al. [46] report that the presence of foreign investors and outside directors is positively associated with the likelihood of choosing Big 4 auditors and paying higher audit fees. Beasley and Petroni [28] report evidence that independent boards tend to select industry specialized auditors.

Most studies discuss managers' opportunistic auditor changes, and in this setting, an effective governance system can increase auditor tenure. However, managers' opportunistic auditor retention can also occur. If a manager has an intimate relationship with an auditor, he/she will retain that auditor longer to receive a favorable audit. In this case, effective governance systems monitor this opportunistic behavior and may lead to a change in auditors, resulting in shorter auditor tenure. Mande and Son [47] show that firms change auditors after financial restatements (i.e., audit failure), and this relation is more pronounced when the quality of corporate governance is high. In this study, we address managers' opportunistic auditor retention, auditor tenure, and the role of unions as a form of governance to monitor them. In addition, we further investigate the direction of audit change associated with unions.

\subsection{Hypothesis Development}

The literature has documented that unions are rent-seekers (Klasa et al. [48]; Matsa [49]; Connolly et al. [6]). Labor unions try to capture increased profits as much as they can through collective bargaining, and practical evidence shows that the wages determined in collective bargaining are increased as the accounting earnings of the company increase (Blanchflower et al. [50]). As a result of this rent-seeking behavior of labor unions, managers of a firm with organized unions tend to report lower profits or conceal their resources and accurate financial information (DeAngelo and DeAngelo [51]; Mora and Sabater [52]; Hilary [16]; Chung et al. [35]). On the other hand, as informed unions have an advantageous position in wage negotiations (Kleiner and Bouillon [13]), they need high-quality financial information (Leung et al. [14], Appelbaum and Hunter [15]). Therefore, unions, as an important firm stakeholder, demand high-quality financial information, whereas managers, the providers of the financial information, have incentives to conceal the true financial figures and manage the earnings discretionally. Several studies regarding the financial information of unionized firms have focused on the perspective of managers as providers of information; however, in this study, we focus on the perspective of unions as demanders of information.

The primary motivation for external audits is to resolve the conflicts caused by information asymmetry between the manager and external shareholders (Lee [53]). Similarly, as managers have information superiority over their employees (Leap et al. [54]), labor unions want to resolve the information asymmetry by independent external audits. Kohlbeck and Mayhew [55] suggest that insiders are likely to conceal information and prefer lower-quality audits in financial reporting in order to protect their private benefits. In this regard, managers, who are providers of financial information, may act as insiders and might want lower-quality audits (Cheng et al. [19]). Since wage negotiations are primarily based on the performance outlined in financial statements, unions, as demanders of information, need an independent and capable auditor to prevent opportunistic earnings management that serves managers' private purposes.

According to DeAngelo [37], audit quality is a function of both the auditor's knowledge (or expertise) to detect errors and the auditor's independence. In this regard, auditor tenure can cause conflicting effects on audit quality. In a positive way, a longer auditor tenure enhances the auditor's client-specific knowledge and technical expertise, both of which increase audit quality (Myers et al. [38]; Geiger and Raghunandan [39]; Johnson et al. [40]). In a negative way, though, as the auditor tenure increases, the resulting close auditor-client relationship can impair auditor independence and cause the auditor to subconsciously act in favor of management, which could decrease audit quality (Deis and Giroux. [56]; Carey and Simnett. [29]; Davis et al. [30]; Dopuch et al. [31]). If there is no difference 
between companies with a union and companies without one in terms of the knowledge improvement effect of the auditor tenure, then auditor tenure can negatively affect the audit quality of companies with a union. This is because, given managers' tendency to hide information from the union, the long-term ties between the auditor and management provide a favorable environment for obtaining audit results in accordance with the manager's intention. Therefore, companies with a union much more likely to have a low-quality audit with a longer auditor tenure than companies without a union. Accordingly, unions that want high-quality audits in order to obtain reliable and transparent financial information will be concerned with the long-term relationship between auditors and managers and request more frequent auditor changes. We thus expect that labor unions will demand a higher audit quality and that this demand will be manifested in the decision of the frequency of auditor change and thus the length of auditor tenure.

Based on the above discussion, we hypothesize that firms with organized unions, ceteris paribus, may face a demand for high auditor independence and thus tend to have shorter auditor tenure.

Hypothesis 1a. There is a negative association between the presence of labor unions and auditor tenure.

In addition, when the power of unions is stronger, their requests for more frequent auditor changes are expected to be stronger, thereby succeeding in reducing the auditor tenure. Thus, we further hypothesize that the power of unions will negatively affect auditor tenure.

Hypothesis $\mathbf{1 b}$. There is a negative association between the strength of unions and auditor tenure.

When unions ask firms for more frequent replacements of auditors, they demand a change to a high-quality auditor. Therefore, we predict that when an auditor replacement occurs, unions are likely to request a change to a higher-quality auditor. While there is conflicting evidence in terms of audit quality associated with Big N auditors, industry specialist auditors tend to provide high-quality audits. Based on the discussion above, the hypothesis is described in an alternative form as follows:

Hypothesis 2a. When an auditor change occurs, firms with a union are more likely to appoint an industry specialist auditor.

When the power of a union is stronger, it would be easier for the union to become involved in the auditor selection process, which increases the probability of selecting a high-quality auditor in appearance. Thus, we additionally hypothesize that the power of a union will affect the auditor change towards an industry specialist auditor.

Hypothesis $\mathbf{2 b}$. When an auditor change occurs, firms with a stronger union are more likely to appoint an industry specialist auditor.

\section{Research Design and Sample Selection}

\subsection{Research Design}

To investigate whether unionization is associated with auditor tenure, we estimate ordinary least square regressions in Equation (1) as the baseline model.

$$
\begin{aligned}
\text { TENURE }_{i t}= & \alpha+\beta 1 \text { UNION }_{i t}\left(\text { UNIONRATE }_{i t}\right)+\beta 2 \text { SIZE }_{i t}+\beta 3 \text { LOSS }_{i t}+\beta 4 O C F_{i t} \\
& +\beta 5 \text { ROA }_{i t}+\beta 6 \text { INVREC }_{i t}+\beta 7 C O N S O L_{i t}+\sum I N D+\sum Y E A R+\varepsilon_{i t}
\end{aligned}
$$

where

TENURE: natural logarithm of consecutive external audit years; 
UNION: 1 if the firm has unionized labor and 0 otherwise;

UNIONRATE: the number of unionized employees divided by the total number of employees;

SIZE: natural logarithm of total assets;

LOSS: 1 if the net income is negative and 0 otherwise;

$O C F$ : operating cash flows divided by total assets;

ROA: net income divided by total assets;

INVREC: sum of inventory and accounts receivable divided by total assets; and

CONSOL: 1 if the firm reports consolidated financial statements and 0 otherwise.

The dependent variable in Equation (1) is TENURE, which is the natural logarithm of auditor tenure, and the variable of interest for Hypothesis 1a is UNION, which indicates the presence of a union. UNIONRATE, another variable of interest for $\mathrm{H} 1 \mathrm{~b}$, is the ratio of the number of unionized employees to the total number of employees. If the presence of a union is associated with auditor tenure, the coefficient of UNION will be significantly negative. In addition, auditor tenure decreases as the strength of the union increases, and the coefficient of UNIONRATE also shows a significantly negative value.

We then turn to test whether the presence of a union is associated with the selection of auditors when an auditor replacement occurs. We estimate the following logistic regression to test Hypothesis $2 \mathrm{a}, \mathrm{b}$.

$$
\begin{aligned}
\left.\operatorname{ISPE1}_{(2)}\right)_{i t}=\alpha & +\beta \text { IUNION }_{i t}\left(\text { UNIONRATE }_{i t}\right)+\beta 2 \text { SIZE }_{i t}+\beta 3 \text { LOSS }_{i t}+\beta 4 O C F_{i t} \\
& +\beta 5 \text { ROA }_{i t}+\beta 6 I_{N V R E C} i t+\beta 7 C O N S O L_{i t}+\sum I N D+\sum Y E A R+\varepsilon_{i t}
\end{aligned}
$$

where

ISPE1: 1 if the auditor changes to the auditor with the largest number of clients in the industry and 0 otherwise and

ISPE2: 1 if the auditor changes to the auditor with the largest market share of annual audit revenue from clients in the industry and 0 otherwise.

See Equation (1) for the definitions of the other variables.

While prior studies have introduced several proxies to measure audit quality, we use industry specialist auditors. Prior studies provide empirical evidence that industry specialist auditors offer better assurance of the quality of financial information than non-industry specialist auditors (Balsam et al. [57]; Krishnan [58]; Carcello and Nagy [59]; Reichelt and Wang [60]; DeBoskey and Jiang [61]). In addition, studies on capital market reactions associated with industry specialist auditors document that firms that are audited by an industry expert elicit a positive market reaction (Knechel et al. [62]).

To define an industry specialist auditor, the dependent variable for Hypotheses $2 a$ and $2 b$ in Equation (2), we utilize two measures (following prior studies): the number of clients and audit fees (Craswell and Taylor [63]; DeFond et al. [64]; Ferguson and Stokes [65]; Craswell et al. [66]). ISPE1 is an indicator variable that takes a value of 1 if a firm changes its auditor to an industry specialist auditor, which is defined as the auditor with the largest number of clients in a given industry in a given year. ISPE2 is a dummy variable that indicates a change in auditor to the industry specialist with the largest market share in terms of audit fees per industry in a given year. If a union is associated with a change in auditor to an industry specialist, the coefficient of UNION (or UNIONRATE) ( $\beta 1$ ) is significantly positive.

In models (1) and (2), we include various control variables to control for the firm-specific characteristics that are likely to affect auditor tenure and auditor choice (Choi and Wong [67]; Simunic and Stein [68]; Pierre and Anderson [69]; Hope et al. [70]). Total asset (SIZE), inventory and accounts receivable ratio (INVREC), and whether a firm reports consolidated financial statements (CONSOL) are included to control for firms' size and complexity. We include net loss (LOSS), the ratio of operating cash flow to total assets $(O C F)$ and return on assets $(R O A)$ to control for the possible impact of firms' profitability on auditor selection. 


\subsection{Sample Selection}

We hand-collect the unionization data, such as the presence of a labor union, the number of unionized employees, and the affiliation group, from firms' annual reports. For accounting and audit-related data, we use the KIS-VALUE III database. Our sample period is from 2006 to 2008. Our sample period is limited to 2008 because that year is the last year for which unionization details are disclosed in annual reports in Korea.

The sample selection processes are described in Table 1. Firms in the financial industry are excluded since their financial statement formats and accounting characteristics are different from those of other industries, which makes it difficult to perform empirical analyses. Firms whose fiscal end is not the end of December are excluded to control for the difference in closing periods, and firms without financial data in KIS-VALUE III are excluded. Lastly, we exclude firms that are in both the Minju and Hanguk union groups because the characteristics of these firms are not clear. This process yields a total of 4568 firm-year observations. Among the total sample, 1751 is the unionized sample, while 2817 is the non-unionized sample.

Table 1. Sample selection.

\begin{tabular}{cc}
\hline Nonfinancial Firms Listed in Korea from 2005 to 2008 & $\mathbf{6 5 6 4}$ \\
\hline (-) Firms with non-December fiscal year-end & 287 \\
(-) Firms without financial data & 1709 \\
(-) Firms affiliated with both Minju and Hanguk & 30 \\
Final Sample & 4568 \\
-Union Sample & 1751 \\
-Non-Union Sample & 2817 \\
\hline
\end{tabular}

\section{Empirical Result}

\subsection{Basic Statistics and Correlation}

Table 2 describes the basic statistics of the variables used in this study. Panel A of Table 2 reports the basic statistics of the total sample. The natural logarithm of the consecutive audit period (TENURE) is on average 1.195, which is approximately 4 years. The maximum value of TENURE is 3.091, which is 22 years. The portion of the sample firms that change their external auditors to industry specialists is $11.6 \%$ in terms of the number of clients (ISPE1) and 10.9\% in terms of audit fees (ISPE2), on average. Additionally, on average, $38.4 \%$ of the total sample has a labor union in their organization, and $17.3 \%$ of total employees join the labor union. The natural logarithm of total assets is 18.609 , which is approximately 113,000 USD. Operating cash flows and net income scaled by total assets are 0.040 and -0.002 , respectively, and $27.1 \%$ of the sample reports losses on average.

Panel B of Table 2 compares the statistics of the unionized sample to those of the non-unionized sample. In the unionized sample (1), the mean (median) value of auditor tenure is 1.157 (1.099), while in the non-unionized sample (2), the mean (median) value is 1.218 (1.386). The mean (median) value of the difference between these two groups is $-0.061(-0.287)$, which is statistically significant, according to a t-test (Wilcoxon Z-test). This result indicates that auditor tenure in the unionized sample is significantly shorter than that of the non-unionized sample. The portion of firms that change their auditors to industry specialist auditors is significantly larger in the unionized sample (ISPE1 0.144, ISPE2 0.138) than in the non-unionized sample (ISPE1 0.099, ISPE2 0.092). Firms in the unionized sample are, on average, larger (SIZE) and more profitable (LOSS, OCF, ROA).

Table 3 reports the Pearson and Spearman correlation between the variables used in this study. The presence of a labor union (UNION) is negatively associated with external auditor tenure (TENURE) and positively associated with auditor changes to industry specialists (ISPE1, ISPE2). Unions are also positively associated with SIZE, OCF, ROA and CONSOL but negatively associated with LOSS. 
Table 2. Descriptive statistics.

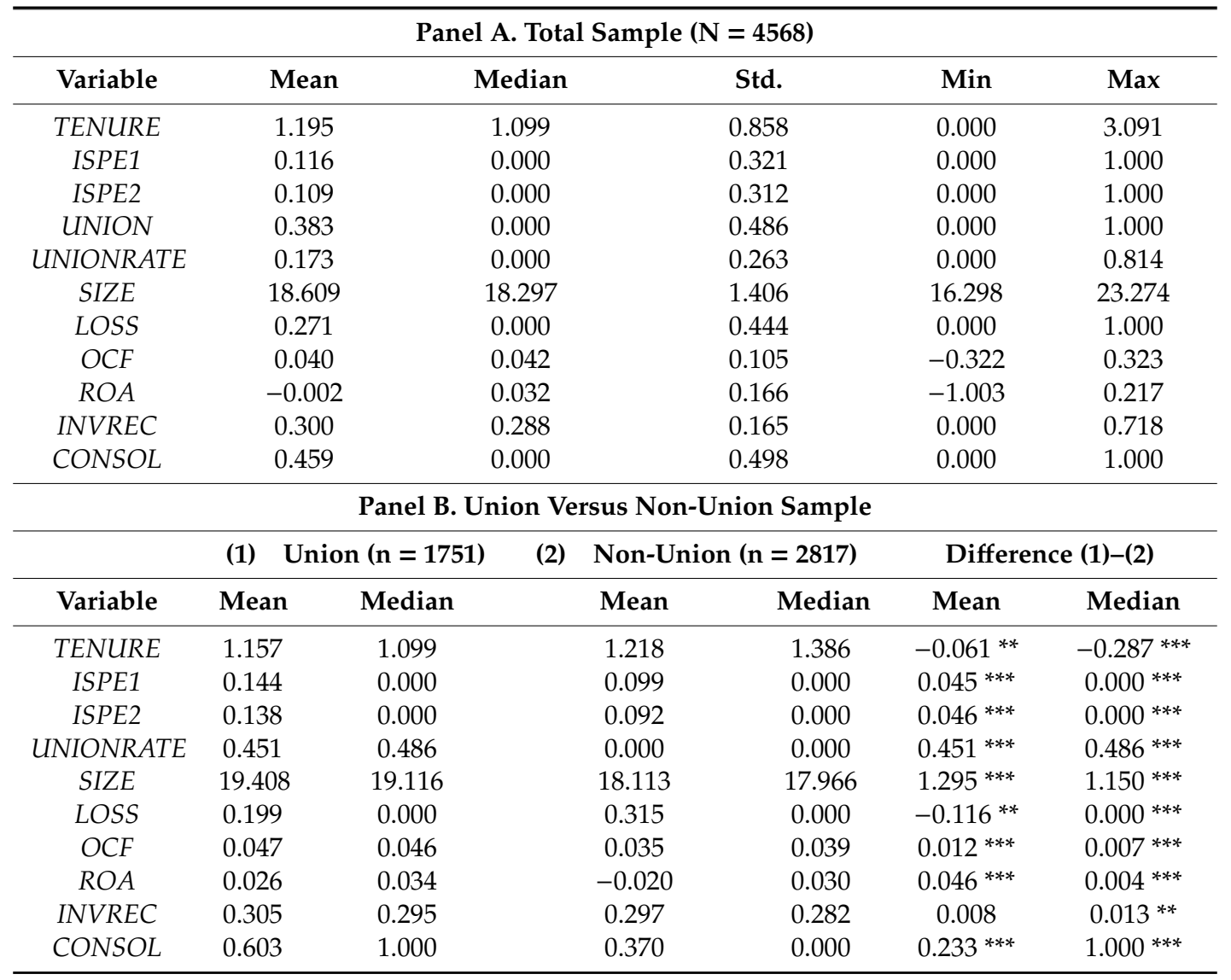

This table reports the descriptive statistics for the variables used in our study. Panel A reports the basic statistics of the full sample. Panel B reports the statistics of the union sample and non-union sample separately, including the statistical significance of the difference in the mean and median values between the UNION and non-UNION samples using a t-test (mean) and a Wilcoxon $\mathrm{z}$-test (median) at the $5 \%$ and $1 \%$ levels marked as ${ }^{* *},{ }^{* * *}$, respectively. See Appendix A for the definitions of the variables.

Table 3. Pearson and Spearman correlations $(\mathrm{N}=4568)$.

\begin{tabular}{|c|c|c|c|c|c|c|c|c|c|c|}
\hline & ISPE1 & ISPE2 & UNION & UNIONR & ITESIZE & LOSS & OCF & $R O A$ & INVREC & CONSOI \\
\hline TENURE & $\begin{array}{l}-0.056 \\
(0.000)\end{array}$ & $\begin{array}{l}-0.034 \\
(0.020)\end{array}$ & $\begin{array}{l}-0.035 \\
(0.019)\end{array}$ & $\begin{array}{l}-0.014 \\
(0.360)\end{array}$ & $\begin{array}{c}0.018 \\
(0.226)\end{array}$ & $\begin{array}{c}-0.062 \\
(<0.0001)\end{array}$ & $\begin{array}{c}0.078 \\
(<0.0001)\end{array}$ & $\begin{array}{c}0.060 \\
(<0.0001)\end{array}$ & $\begin{array}{l}-0.002 \\
(0.883)\end{array}$ & $\begin{array}{l}-0.027 \\
(0.064)\end{array}$ \\
\hline ISPE1 & 1.000 & $\begin{array}{c}0.845 \\
(<0.0001)\end{array}$ & $\begin{array}{c}0.068 \\
(<0.0001)\end{array}$ & $\begin{array}{c}0.062 \\
(<0.0001)\end{array}$ & $\begin{array}{c}0.031 \\
(0.035)\end{array}$ & $\begin{array}{l}-0.017 \\
(0.249)\end{array}$ & $\begin{array}{c}0.039 \\
(0.009)\end{array}$ & $\begin{array}{c}0.068 \\
(<0.0001)\end{array}$ & $\begin{array}{c}0.062 \\
(<0.0001)\end{array}$ & $\begin{array}{c}0.096 \\
(<0.0001)\end{array}$ \\
\hline ISPE2 & $\begin{array}{c}0.845 \\
<0.0001\end{array}$ & 1.000 & $\begin{array}{c}0.072 \\
(<0.0001)\end{array}$ & $\begin{array}{c}0.075 \\
(<0.0001)\end{array}$ & $\begin{array}{c}0.034 \\
(0.020)\end{array}$ & $\begin{array}{l}-0.016 \\
(0.291)\end{array}$ & $\begin{array}{c}0.052 \\
(0.001)\end{array}$ & $\begin{array}{c}0.072 \\
(<0.0001)\end{array}$ & $\begin{array}{c}0.075 \\
(<0.0001)\end{array}$ & $\begin{array}{c}0.109 \\
(<0.0001)\end{array}$ \\
\hline UNION & $\begin{array}{c}0.068 \\
<0.0001\end{array}$ & $\begin{array}{c}0.072 \\
<0.0001\end{array}$ & 1.000 & $\begin{array}{c}0.835 \\
(<0.0001)\end{array}$ & $\begin{array}{c}0.448 \\
(<0.0001)\end{array}$ & $\begin{array}{c}-0.127 \\
(<0.0001)\end{array}$ & $\begin{array}{c}0.053 \\
(0.000)\end{array}$ & $\begin{array}{c}0.135 \\
(<0.0001)\end{array}$ & $\begin{array}{c}0.024 \\
(0.109)\end{array}$ & $\begin{array}{c}0.228 \\
(<0.0001)\end{array}$ \\
\hline UNIONRATE & $\begin{array}{c}0.069 \\
<0.0001\end{array}$ & $\begin{array}{c}0.077 \\
<0.0001\end{array}$ & $\begin{array}{c}0.958 \\
<0.0001\end{array}$ & 1.000 & $\begin{array}{c}0.398 \\
(<0.0001)\end{array}$ & $\begin{array}{c}-0.094 \\
(<0.0001)\end{array}$ & $\begin{array}{c}0.060 \\
(<0.0001)\end{array}$ & $\begin{array}{c}0.113 \\
(<0.0001)\end{array}$ & $\begin{array}{l}-0.000 \\
(0.975)\end{array}$ & $\begin{array}{c}0.201 \\
(<0.0001)\end{array}$ \\
\hline SIZE & $\begin{array}{c}0.093 \\
<0.0001\end{array}$ & $\begin{array}{c}0.102 \\
<0.0001\end{array}$ & $\begin{array}{c}0.455 \\
<0.0001\end{array}$ & $\begin{array}{c}0.449 \\
<0.0001\end{array}$ & 1.000 & $\begin{array}{c}-0.254 \\
<0.0001\end{array}$ & $\begin{array}{c}0.130 \\
<0.0001\end{array}$ & $\begin{array}{c}0.266 \\
<0.0001\end{array}$ & $\begin{array}{c}-0.144 \\
<0.0001\end{array}$ & $\begin{array}{c}0.482 \\
<0.0001\end{array}$ \\
\hline LOSS & $\begin{array}{c}-0.036 \\
0.014\end{array}$ & $\begin{array}{c}-0.030 \\
0.042\end{array}$ & $\begin{array}{l}-0.126 \\
<0.0001\end{array}$ & $\begin{array}{l}-0.117 \\
<0.0001\end{array}$ & $\begin{array}{l}-0.279 \\
<0.0001\end{array}$ & 1.000 & $\begin{array}{l}-0.385 \\
<0.0001\end{array}$ & $\begin{array}{l}-0.638 \\
<0.0001\end{array}$ & $\begin{array}{l}-0.086 \\
<0.0001\end{array}$ & $\begin{array}{c}-0.048 \\
0.001\end{array}$ \\
\hline$O C F$ & $\begin{array}{l}0.036 \\
0.015\end{array}$ & $\begin{array}{l}0.036 \\
0.016\end{array}$ & $\begin{array}{l}0.041 \\
0.005\end{array}$ & $\begin{array}{l}0.051 \\
0.001\end{array}$ & $\begin{array}{c}0.106 \\
<0.0001\end{array}$ & $\begin{array}{c}-0.386 \\
<0.0001\end{array}$ & 1.000 & $\begin{array}{c}0.471 \\
<0.0001\end{array}$ & $\begin{array}{c}-0.135 \\
<0.0001\end{array}$ & $\begin{array}{l}0.026 \\
0.084\end{array}$ \\
\hline$R O A$ & $\begin{array}{l}0.031 \\
0.038\end{array}$ & $\begin{array}{l}0.036 \\
0.014\end{array}$ & $\begin{array}{l}0.054 \\
0.000\end{array}$ & $\begin{array}{l}0.046 \\
0.002\end{array}$ & $\begin{array}{c}0.220 \\
<0.0001\end{array}$ & $\begin{array}{c}-0.769 \\
<0.0001\end{array}$ & $\begin{array}{c}0.501 \\
<0.0001\end{array}$ & 1.000 & $\begin{array}{l}0.039 \\
0.008\end{array}$ & $\begin{array}{c}0.066 \\
<0.0001\end{array}$ \\
\hline INVREC & $\begin{array}{c}-0.018 \\
0.234\end{array}$ & $\begin{array}{c}-0.017 \\
0.254\end{array}$ & $\begin{array}{l}0.029 \\
0.048\end{array}$ & $\begin{array}{l}0.020 \\
0.174\end{array}$ & $\begin{array}{c}-0.082 \\
<0.0001\end{array}$ & $\begin{array}{c}-0.092 \\
<0.0001\end{array}$ & $\begin{array}{l}-0.130 \\
<0.0001\end{array}$ & $\begin{array}{l}0.054 \\
0.000\end{array}$ & 1.000 & $\begin{array}{l}-0.186 \\
<0.0001\end{array}$ \\
\hline CONSOL & $\begin{array}{l}0.039 \\
0.009\end{array}$ & $\begin{array}{l}0.052 \\
0.001\end{array}$ & $\begin{array}{c}0.228 \\
<0.0001\end{array}$ & $\begin{array}{c}0.226 \\
<0.0001\end{array}$ & $\begin{array}{c}0.489 \\
<0.0001\end{array}$ & $\begin{array}{c}-0.048 \\
0.001\end{array}$ & $\begin{array}{l}0.001 \\
0.954\end{array}$ & $\begin{array}{l}0.009 \\
0.560\end{array}$ & $\begin{array}{l}-0.171 \\
<0.0001\end{array}$ & 1.000 \\
\hline
\end{tabular}

This table reports the Pearson and Spearman correlations. The Pearson correlation coefficient and $p$-value are reported in the upper right triangle, while the Spearman correlation results are reported in the lower left triangle. See Appendix A for the definitions of all variables. 


\subsection{Main Result}

Table 4 shows the results of the regression to test the effect of labor unions on auditor tenure (Hypothesis 1). Column (1) of Table 4 tests the effect of the presence of labor unions, and column (2) tests the effect of labor union power on auditor tenure. In column (1), the coefficient of UNION is -0.128 ( $t$-vale -3.44 ), which suggests that the presence of labor unions is significantly negatively associated with auditor tenure. Consistently, in column (2), a higher unionization rate significantly shortens auditor tenure (coefficient -0.141 , $t$-value -2.21 ). These results indicate that firms with labor unions and stronger unions more often change external auditors than firms without labor unions, which supports Hypothesis 1.

The results for the control variable show that auditor tenure increases as firm size (SIZE) and operating cash flow $(O C F)$ increase. These results may imply that for firms, a larger size (or cash flow) increases audit failure risk following the initial audit, and for the auditor, larger clients provide better economic benefits, both of which result in less auditor change.

Table 4. The impact of labor unions on auditor tenure (Hypothesis 1).

\begin{tabular}{cccc}
\hline Variable & Expected Sign & $\mathbf{( 1 )}$ & $\mathbf{( 2 )}$ \\
\hline Intercept & & 0.477 & $0.638^{* *}$ \\
UNION & - & $(1.60)$ & $(2.18)$ \\
UNIONRATE & $-0.128^{* *}$ & \\
SIZE & & $(-3.44)$ & \\
& + & & $-0.141^{* *}$ \\
LOSS & - & $0.046^{* * *}$ & $0.037^{* *}$ \\
& & $(2.86)$ & $(2.32)$ \\
OCF & + & 0.006 & 0.008 \\
& & $(0.17)$ & $(0.21)$ \\
ROA & + & $(3.24)$ & $(3.27)$ \\
& & 0.030 & 0.028 \\
INVREC & $-/+$ & $(0.28)$ & $(0.26)$ \\
CONSOL & & -0.027 & -0.048 \\
& + & $(-0.30)$ & $(-0.51)$ \\
Industry, year dummy & -0.051 & -0.053 \\
N & & $(-1.59)$ & $(-1.66)$ \\
\hline Adjusted $R^{2}$ & & included & included \\
\hline
\end{tabular}

This table reports the results on the association between labor unions and external auditor tenure. Columns (1) and (2) report the impact of labor unions and the unionization rate, respectively. TENURE $=\alpha+\beta 1 U N I O N$ (UNIONRATE) $+\beta 2$ Controls $+\varepsilon$ T-statistics are presented below the coefficient within parentheses. Standard errors are clustered by firm level. Coefficient and t-statistics colored are directly related to our hypothesis. See Appendix A for the definitions of all variables. ${ }^{* *}$, and ${ }^{* *}$ indicate significance at the $5 \%$ and $1 \%$ levels, respectively.

Table 5 reports the results on the effect of labor unions on auditor changes to industry specialized auditors (Hypothesis 2). We use firm-year observations of auditor changes, which limits the number of observations to 1069. The dependent variable ISPE indicates that a firm changes its auditor from a non-industry specialist to an industry specialist, where an industry specialist is defined by two criteria: number of clients (ISPE1) and audit fees (ISPE2). Columns (1) and (2) show the results where the industry specialist is classified by the number of audit clients (ISPE1). In column (1), the variable of UNION is significantly positive (coefficient $0.317, t$-value 1.76). This result suggests that when labor unions exist, firms are more likely to select industry specialist auditors when they change external auditors. In column (2), the unionization rate (UNIONRATE) is significantly positive (coefficient $0.317, t$-value 1.76 ; coefficient $0.719, t$-value 2.31 , respectively), which is consistent with the result of column (1).

Columns (3) and (4) report the results where we use another industry specialist definition, audit fee (ISPE2). In column (3), UNION is not significant but is positive, and in column (4), UNIONRATE is significantly positive (coefficient $0.767, t$-value 2.36 ). These results suggest consistent results that the 
labor union, especially when the union power is stronger, exercises pressure on firms to select more specialized auditors in the auditor change process, which supports Hypothesis 2.

Table 5. The impact of labor unions on auditor change to an industry specialist (Hypothesis 2).

\begin{tabular}{|c|c|c|c|c|c|}
\hline \multirow{2}{*}{ Variable } & \multirow{2}{*}{ Expected Sign } & \multicolumn{2}{|c|}{ ISPE1 } & \multicolumn{2}{|c|}{ ISPE2 } \\
\hline & & (1) & (2) & (3) & (4) \\
\hline Intercept & & $\begin{array}{c}-3.593^{* * *} \\
(-2.61)\end{array}$ & $\begin{array}{c}-3.544^{* * *} \\
(-2.62)\end{array}$ & $\begin{array}{c}-3.976^{* * *} \\
(-2.67)\end{array}$ & $\begin{array}{c}-3.776^{* *} \\
(-2.57)\end{array}$ \\
\hline UNION & + & $\begin{array}{c}0.317^{*} \\
(1.76)\end{array}$ & & $\begin{array}{l}0.284 \\
(1.53)\end{array}$ & \\
\hline UNIONRATE & + & & $\begin{array}{c}0.719^{* *} \\
(2.31)\end{array}$ & & $\begin{array}{c}0.767^{* *} \\
(2.36)\end{array}$ \\
\hline SIZE & + & $\begin{array}{l}0.126^{*} \\
(1.69)\end{array}$ & $\begin{array}{l}0.122 * \\
(1.69)\end{array}$ & $\begin{array}{c}0.144 * \\
(1.81)\end{array}$ & $\begin{array}{l}0.131^{*} \\
(1.68)\end{array}$ \\
\hline LOSS & - & $\begin{array}{l}-0.144 \\
(-0.58)\end{array}$ & $\begin{array}{l}-0.148 \\
(-0.60)\end{array}$ & $\begin{array}{l}-0.124 \\
(-0.48)\end{array}$ & $\begin{array}{l}-0.131 \\
(-0.51)\end{array}$ \\
\hline$O C F$ & + & $\begin{array}{l}-0.398 \\
(-0.44)\end{array}$ & $\begin{array}{l}-0.438 \\
(-0.48)\end{array}$ & $\begin{array}{l}-0.956 \\
(-0.88)\end{array}$ & $\begin{array}{l}-1.015 \\
(-0.93)\end{array}$ \\
\hline$R O A$ & + & $\begin{array}{l}-0.028 \\
(-0.04)\end{array}$ & $\begin{array}{l}-0.032 \\
(-0.04)\end{array}$ & $\begin{array}{l}0.216 \\
(0.27)\end{array}$ & $\begin{array}{l}0.209 \\
(0.26)\end{array}$ \\
\hline INVREC & $-/+$ & $\begin{array}{l}0.168 \\
(0.32)\end{array}$ & $\begin{array}{l}0.199 \\
(0.37)\end{array}$ & $\begin{array}{l}0.080 \\
(0.14)\end{array}$ & $\begin{array}{l}0.105 \\
(0.18)\end{array}$ \\
\hline CONSOL & + & $\begin{array}{l}-0.243 \\
(-1.25)\end{array}$ & $\begin{array}{l}-0.244 \\
(-1.26)\end{array}$ & $\begin{array}{l}-0.120 \\
(-0.60)\end{array}$ & $\begin{array}{l}-0.123 \\
(-0.61)\end{array}$ \\
\hline \multicolumn{2}{|c|}{ Industry, year dummy } & \multicolumn{2}{|c|}{ included } & \multicolumn{2}{|c|}{ included } \\
\hline $\begin{array}{c}N \\
\text { Pseudo } R^{2}\end{array}$ & & $\begin{array}{l}1069 \\
0.022\end{array}$ & $\begin{array}{l}1069 \\
0.024\end{array}$ & $\begin{array}{l}1069 \\
0.027\end{array}$ & 1069 \\
\hline
\end{tabular}

This table reports the results regarding the association between labor unions and external auditor tenure. Columns (1) and (3) report the impact of the presence of labor unions, while columns (2) and (4) report the impact of the unionization rate. ISPE1(2) $=\alpha+\beta 1 U N I O N(U N I O N R A T E)+\beta 3$ Controls $+\varepsilon$ Z-statistics are presented below the coefficient within parentheses. Standard errors are clustered by firm level. The coefficients and $t$-statistics that are colored are directly related to our hypothesis. See Appendix A for the definitions of all variables. ***, and *** indicate significance at the $10 \%, 5 \%$ and $1 \%$ levels, respectively.

\subsection{Additional Analysis}

\subsubsection{Impact of the Affiliation of a Labor Union}

In the main analysis, we use the unionization rate as a proxy for labor union power because this proxy is the most frequently used in the extant literature (Bronars and Deere [71]; Hilary [16]; Matsa [49]). In this section, we additionally test the effect of union power using the union federation with which each firm's union is affiliated.

In Korea, most labor unions are affiliated with either the Minju or Hanguk federation. Chung et al. [18] report that 89 percent of labor unions are affiliated with one of these two federations. The approaches and strategies of each federation are quite different. Minju is known as the "strong union federation" that is quite aggressive and often goes on strike, while Hanguk is known as the "moderate union" that tends to compromise with management on key issues. These contrary characteristics may affect auditor tenure or the direction of auditor change differently. We perform additional tests on the effect of each labor union affiliation. If the stronger union has a higher demand for high-quality audits and a higher negotiation power, the variable MINJU will show a more significant association with the proxy for audit quality. Based on the above discussion, we hypothesize that the labor union affiliation with Minju is negatively associated with audit tenure and positively associated with the selection of an industry specialist auditor. We test this hypothesis using the following equation:

$$
\begin{aligned}
& \text { TENURE }=\alpha+\beta 1 \text { MINJU }+\beta 2 \text { HANGUK }+\beta 3 \text { NOCHAIN }+\beta 4 \text { Controls }+\varepsilon . \\
& \text { ISPE1 }(2)=\alpha+\beta 1 \text { MINJU }+\beta 2 \text { HANGUK }+\beta 3 \text { NOCHAIN }+\beta 4 \text { Controls }+\varepsilon .
\end{aligned}
$$

where 
MINJU: 1 if the union of the firm belongs to the Minju Confederation of Korean Trade;

HANGUK: 1 if the union of the firm belongs to the Hanguk Confederation of Korean Trade;

NOCHAIN: 1 if the union of the firm does not belong to any federation, and 0 otherwise.

The results are shown in Table 6. Column (1) reveals the effect of each affiliation on auditor tenure. It reports that auditor tenure is shorter when the labor union is affiliated with Minju (MINJU -0.196, $t$-value -3.61) or Hanguk (HANGUK -0.107 , $t$-value -2.61 ). When the labor union is affiliated with neither of these federations (NOCHAIN), auditor tenure has no association with the presence of a labor union. Columns (2) and (3) report the effect of an auditor change to an industry specialist. In both measures of industry specialist auditors, the variable MINJU is statistically significantly positive (ISPE1 $0.695, t$-value 2.74; ISPE2 0.747, $t$-value 2.90), while the remaining variables, HANGUK and NOCHAIN, are positive but not statistically significant. These results are consistent with the main results, which indicate that a stronger labor union demands a high-quality audit, which shortens auditor tenure and increases the likelihood of an auditor change to an industry specialist.

Table 6. The impact of labor unions by union affiliation group.

\begin{tabular}{|c|c|c|c|}
\hline \multirow{2}{*}{ Variable } & \multirow{2}{*}{ Tenure } & \multicolumn{2}{|c|}{ Industry Specialist } \\
\hline & & ISPE1 & ISPE2 \\
\hline Intercept & $\begin{array}{l}0.442 \\
(1.48)\end{array}$ & $\begin{array}{c}-3.472^{* *} \\
(-2.54)\end{array}$ & $\begin{array}{c}-3.804^{* * *} \\
(-2.59)\end{array}$ \\
\hline MINJU & $\begin{array}{c}-0.196^{* * *} \\
(-3.61)\end{array}$ & $\begin{array}{c}0.695^{* * *} \\
(2.74)\end{array}$ & $\begin{array}{c}0.747^{* * *} \\
(2.90)\end{array}$ \\
\hline HANGUK & $\begin{array}{c}-0.107^{* * *} \\
(-2.61)\end{array}$ & $\begin{array}{l}0.165 \\
(0.79)\end{array}$ & $\begin{array}{l}0.055 \\
(0.25)\end{array}$ \\
\hline NOCHAIN & $\begin{array}{l}-0.116 \\
(-1.45)\end{array}$ & $\begin{array}{l}0.195 \\
(0.42)\end{array}$ & $\begin{array}{l}0.352 \\
(0.75)\end{array}$ \\
\hline SIZE & $\begin{array}{c}0.048^{* * *} \\
(2.97)\end{array}$ & $\begin{array}{l}0.120 \\
(1.62)\end{array}$ & $\begin{array}{l}0.136 \text { * } \\
(1.73)\end{array}$ \\
\hline LOSS & $\begin{array}{l}0.004 \\
(0.11)\end{array}$ & $\begin{array}{l}-0.135 \\
(-0.55)\end{array}$ & $\begin{array}{l}-0.108 \\
(-0.41)\end{array}$ \\
\hline OCF & $\begin{array}{c}0.472^{* * *} \\
(3.22)\end{array}$ & $\begin{array}{l}-0.398 \\
(-0.43)\end{array}$ & $\begin{array}{l}-0.971 \\
(-0.88)\end{array}$ \\
\hline$R O A$ & $\begin{array}{l}0.023 \\
(0.21)\end{array}$ & $\begin{array}{l}-0.010 \\
(-0.01)\end{array}$ & $\begin{array}{l}0.261 \\
(0.32)\end{array}$ \\
\hline INVREC & $\begin{array}{l}-0.021 \\
(-0.23)\end{array}$ & $\begin{array}{l}0.100 \\
(0.19)\end{array}$ & $\begin{array}{l}-0.008 \\
(-0.01)\end{array}$ \\
\hline CONSOL & $\begin{array}{l}-0.051 \\
(-1.59)\end{array}$ & $\begin{array}{l}-0.236 \\
(-1.20)\end{array}$ & $\begin{array}{l}-0.105 \\
(-0.52)\end{array}$ \\
\hline Industry, year dummy & included & included & included \\
\hline $\begin{array}{c}\mathrm{N} \\
\text { (Pseudo) R2 }\end{array}$ & $\begin{array}{l}4568 \\
0.089\end{array}$ & $\begin{array}{c}1069 \\
0.0262\end{array}$ & $\begin{array}{c}1069 \\
0.0338\end{array}$ \\
\hline
\end{tabular}

This table reports the estimation results of auditor tenure and auditor changes as a function of each labor affiliation group (MINJU, HANGU and NOCHAIN). Column (1) indicates the impact on auditor tenure using the following equation: TENURE $=\alpha+\beta 1 M I N J U+\beta 2$ HANGUK $+\beta 3$ NOCHAIN $+\beta 4$ Controls $+\varepsilon$. Columns (2) and (3) report the effect on auditor changes to an industry specialist using the following equation: ISPE1 $(2)=\alpha+\beta 1 M I N J U+$ $\beta 2$ HANGUK $+\beta 3$ NOCHAIN $+\beta 4$ Controls $+\varepsilon$. T-statistics (z-statistics) are presented below the coefficient within parentheses. Standard errors are clustered by firm level. The coefficients and t-statistics that are colored are directly related to our hypothesis. See Appendix A for the definitions of all variables. ${ }^{*}, * *$, and ${ }^{* * *}$ indicate significance at the $10 \%, 5 \%$ and $1 \%$ levels, respectively.

\subsubsection{Auditor Changes to a Big 4 Audit Firm}

While we define high-quality auditors as industry specialists for Hypotheses $2 a$ and $2 b$, we test whether the results are consistent when we use Big 4 audit firms as a proxy for high-quality auditors. The extant literature on the audit quality of Big 4 audit firms reports inconsistent results (Becker et al. [72]; Lawrence et al. [73]; Eshleman and Guo [74]). However, many previous studies have also used the Big 4 dichotomy as a popular proxy for audit quality. Dopuch and Simunic [75] suggest that general investors consider Big 4 auditors to provide high-quality audits, which differentiates Big 4 auditors from non-Big 4 auditors. Therefore, notwithstanding the mixed empirical results in previous 
studies, big audit firms are generally perceived as high-quality auditors, which may lead labor unions to prefer Big 4 audit firms. Additionally, in the external auditor change process, a labor union is more likely to exert pressure on a firm to hire a Big 4 audit firm. Thus, we hypothesize that the existence and power of the labor union increase the auditor changes from non-Big4 to Big4. We perform a regression using Big 4 auditors as a proxy for audit quality using the following equation:

$$
\begin{aligned}
\operatorname{BIGCH1}_{(2,3,4)_{i t}=} & \alpha+\beta 1 \mathrm{UNION}_{i t}\left(\text { UNIONRATE }_{i t}\right)+\beta 2 \mathrm{SIZE}_{i t}+\beta 3 \mathrm{LOSS}_{i t}+\beta 4 O C F_{i t} \\
& +\beta 5 \mathrm{ROA}_{i t}+\beta 6 \operatorname{INVREC}_{i t}+\beta 7 \mathrm{CONSOL}_{i t}+\sum \operatorname{IND}+\sum Y E A R+\varepsilon i t
\end{aligned}
$$

where

BIGCH1: 1 if the auditor changes to a Big 4 from a non-Big 4;

BIGCH2: 1 if the auditor changes to a Big 4 from a Big 4;

BIGCH3: 1 if the auditor changes to a non-Big 4 from a non-Big 4; and

BIGCH4: 1 if the auditor changes to a non-Big 4 from a Big 4 .

See Equation (1) for the definitions of the other variables.

The results are shown in Table 7. The variables UNION and UNIONRATE are statistically significantly positive in only columns (1) and (2), which refer to auditor changes from a non-Big 4 auditor to a Big 4 auditor. This result indicates that the presence and power of labor unions are positively associated with auditor changes from a non-Big 4 to a Big 4 auditor but not with other changes. This result is consistent with the main results in Table 5, as both results suggest that labor unions demand that firms select a high-quality auditor-either a Big 4 auditor or an industry specialist auditor-when firms change external auditors.

\begin{tabular}{|c|c|c|c|c|c|c|c|c|}
\hline \multirow{2}{*}{ Variable } & \multicolumn{2}{|c|}{ BIGCH1 } & \multicolumn{2}{|c|}{$\mathrm{BIGCH} 2$} & \multicolumn{2}{|c|}{ ВIGCH3 } & \multicolumn{2}{|c|}{ BIGCH4 } \\
\hline & (1) & (2) & (3) & (4) & (5) & (6) & (7) & (8) \\
\hline Intercept & $\begin{array}{l}-1.090 \\
(-0.87)\end{array}$ & $\begin{array}{l}-1.407 \\
(-1.14)\end{array}$ & $\begin{array}{c}-16.514 \text { *** } \\
(-9.43)\end{array}$ & $\begin{array}{c}-16.575^{* * * *} \\
(-9.65)\end{array}$ & $\begin{array}{c}9.757^{* * *} \\
(6.28)\end{array}$ & $\begin{array}{c}9.827^{* * * *} \\
(6.55)\end{array}$ & $\begin{array}{c}7.691 \text { *** } \\
(4.77)\end{array}$ & $\begin{array}{c}7.875^{* * * *} \\
(5.00)\end{array}$ \\
\hline UNION & $\begin{array}{c}0.443 \text { *** } \\
(2.62)\end{array}$ & & $\begin{array}{l}-0.110 \\
(-0.58)\end{array}$ & & $\begin{array}{l}-0.117 \\
(-0.61)\end{array}$ & & $\begin{array}{l}-0.096 \\
(-0.50)\end{array}$ & \\
\hline UNIONRATE & & $\begin{array}{c}0.716^{* *} \\
(2.44)\end{array}$ & & $\begin{array}{l}-0.297 \\
(-0.83)\end{array}$ & & $\begin{array}{l}-0.221 \\
(-0.62)\end{array}$ & & $\begin{array}{l}-0.085 \\
(-0.23)\end{array}$ \\
\hline SIZE & $\begin{array}{l}0.048 \\
(0.70)\end{array}$ & $\begin{array}{l}0.067 \\
(0.99)\end{array}$ & $\begin{array}{c}0.752 * * * \\
(8.40)\end{array}$ & $\begin{array}{c}0.756 * * * \\
(8.64)\end{array}$ & $\begin{array}{c}-0.618 * * * \\
(-7.06)\end{array}$ & $\begin{array}{c}-0.622 * * * \\
(-7.39)\end{array}$ & $\begin{array}{c}-0.502 * * * \\
(-5.56)\end{array}$ & $\begin{array}{c}-0.513^{* * *} \\
(-5.83)\end{array}$ \\
\hline LOSS & $\begin{array}{l}-0.152 \\
(-0.61)\end{array}$ & $\begin{array}{l}-0.150 \\
(-0.60)\end{array}$ & $\begin{array}{l}-0.242 \\
(-0.99)\end{array}$ & $\begin{array}{l}-0.237 \\
(-0.97)\end{array}$ & $\begin{array}{l}0.307 \\
(1.45)\end{array}$ & $\begin{array}{l}0.308 \\
(1.45)\end{array}$ & $\begin{array}{l}0.085 \\
(0.36)\end{array}$ & $\begin{array}{l}0.082 \\
(0.35)\end{array}$ \\
\hline OCF & $\begin{array}{l}-0.177 \\
(-0.20)\end{array}$ & $\begin{array}{l}-0.216 \\
(-0.25)\end{array}$ & $\begin{array}{c}3.237^{* * * *} \\
(3.40)\end{array}$ & $\begin{array}{c}3.260^{* * * *} \\
(3.41)\end{array}$ & $\begin{array}{l}0.508 \\
(0.67)\end{array}$ & $\begin{array}{l}0.519 \\
(0.68)\end{array}$ & $\begin{array}{c}-2.706 \text { *** } \\
(-3.18)\end{array}$ & $\begin{array}{c}-2.705^{* * *} \\
(-3.16)\end{array}$ \\
\hline$R O A$ & $\begin{array}{l}1.431 * \\
(1.77)\end{array}$ & $\begin{array}{c}1.451 * * * \\
(1.80)\end{array}$ & $\begin{array}{l}0.125 \\
(0.19)\end{array}$ & $\begin{array}{l}0.140 \\
(0.22)\end{array}$ & $\begin{array}{l}-0.804 \\
(-1.49)\end{array}$ & $\begin{array}{l}-0.805 \\
(-1.49)\end{array}$ & $\begin{array}{c}1.236 * \\
(1.77)\end{array}$ & $\begin{array}{c}1.231 \text { * } \\
(1.77)\end{array}$ \\
\hline INVREC & $\begin{array}{l}0.239 \\
(0.52)\end{array}$ & $\begin{array}{l}0.283 \\
(0.61)\end{array}$ & $\begin{array}{l}0.084 \\
(0.16)\end{array}$ & $\begin{array}{l}0.076 \\
(0.14)\end{array}$ & $\begin{array}{l}0.653 \\
(1.35)\end{array}$ & $\begin{array}{l}0.649 \\
(1.34)\end{array}$ & $\begin{array}{l}-0.596 \\
(-1.22)\end{array}$ & $\begin{array}{l}-0.607 \\
(-1.24)\end{array}$ \\
\hline CONSOL & $\begin{array}{l}-0.219 \\
(-1.21)\end{array}$ & $\begin{array}{l}-0.214 \\
(-1.19)\end{array}$ & $\begin{array}{l}0.068 \\
(0.37)\end{array}$ & $\begin{array}{l}0.069 \\
(0.37)\end{array}$ & $\begin{array}{l}0.199 \\
(1.14)\end{array}$ & $\begin{array}{l}0.200 \\
(1.15)\end{array}$ & $\begin{array}{l}0.045 \\
(0.25)\end{array}$ & $\begin{array}{l}0.045 \\
(0.25)\end{array}$ \\
\hline Ind, year dummy & \multicolumn{2}{|c|}{ included } & \multicolumn{2}{|c|}{ included } & \multicolumn{2}{|c|}{ included } & \multicolumn{2}{|c|}{ included } \\
\hline$N$ & 1077 & 1077 & 1077 & 1077 & 1077 & 1077 & 1077 & 1077 \\
\hline Pseudo $R^{2}$ & 0.110 & 0.109 & 0.241 & 0.241 & 0.108 & 0.108 & 0.073 & 0.073 \\
\hline
\end{tabular}

Table 7. The impact of labor unions on auditor change

This table reports the estimation results of the effect of labor unions on auditor changes using the following equation: BIGCH1 $(2,3,4)_{i t}=\alpha+\beta 1 \mathrm{UNION}_{\text {it }}\left(\mathrm{UNIONRATE}_{\mathrm{it}}\right)+\beta 2 \mathrm{SIZE}_{\mathrm{it}}+\beta 3 \mathrm{LOSS}_{i t}+\beta 4 \mathrm{OCF}_{i t}+\beta 5 \mathrm{ROA}_{i t}+\beta 6 \mathrm{INVREC}_{i t}+$ $\beta 7 \mathrm{CONSOL}_{t}+\sum \mathrm{IND}+\sum \mathrm{YEAR}+\varepsilon$ it BIGCH1 indicates auditor changes from a non-Big 4 auditor to a Big 4 auditor (BIGCH1). See Appendix A for the definitions of all variables. T-statistics are presented below the coefficient within parentheses. Standard errors are clustered by firm level. The coefficients and z-statistics that are colored are directly related to our hypothesis. See Appendix A for the definitions of all variables. ${ }^{*}, *$, and ${ }^{* *}$ indicate significance at the $10 \%, 5 \%$ and $1 \%$ levels, respectively.

We also form alternative sub-samples and apply multinomial logit regression. An un-tabulated result shows that the labor union increases the likelihood of changing from non-Big to Big 4 auditors, which is qualitatively the same as the results presented in Table 7. 


\subsubsection{Propensity Score Matching}

As reported in Panel B of Tables 1 and 2, unionized firms are on average larger and more profitable. Therefore, it is possible that this difference in firm characteristics between unionized and non-unionized firms may affect the results. To avoid the endogeneity issue, we test the robustness of our study using the propensity score matching process (Lawrence et al. [73]). First, we estimate the propensity score using firm characteristics such as firm size (natural logarithm of total assets), financial status measure (leverage, loss, return on assets, cash flow from operations), liquidity measure (current ratio), and growth opportunity (book to market ratio). Then, we match the unionized sample to the non-unionized sample based on the closest propensity score using a caliper distance of $3 \%$, without replacement (Lawrence et al. [73]; Minutti-Meza [76]).

Table 8 shows the results. Panel A of Table 8 reports the effect of labor unions on auditor tenure. The variables UNION and UNIONRATE are significantly negative, which is qualitatively the same as the main result. In Panel B of Table 8, in both industry specialist indicators, ISPE1 and ISPE2, the variables UNION and UNIONRATE are significantly positive, which is also consistent with the main result. These results suggest the robustness of our findings.

Table 8. The impact of labor unions using propensity score matching.

\begin{tabular}{ccc}
\hline & Panel A. Auditor Tenure & \\
\hline Variable & $\mathbf{( 1 )}$ & $\mathbf{( 2 )}$ \\
\hline Intercept & 0.585 & 0.577 \\
UNION & $(1.20)$ & $(1.17)$ \\
UNIONRATE & $0.113^{* * *}$ & \\
& $(-2.81)$ & $-0.127^{*}$ \\
SIZE & & $(-1.78)$ \\
LOSS & $0.051^{* *}$ & $0.051^{*}$ \\
& $(1.98)$ & $(1.93)$ \\
OCF & 0.012 & 0.016 \\
& $(0.22)$ & $(0.29)$ \\
ROA & 0.283 & 0.279 \\
& $(1.34)$ & $(1.32)$ \\
INVREC & -0.104 & -0.084 \\
& $(-0.45)$ & $(-0.36)$ \\
CONSOL & $-0.250^{* *}$ & $-0.262^{* *}$ \\
& $(-1.99)$ & $(-2.08)$ \\
Industry, year dummy & $-0.076^{*}$ & $-0.075^{*}$ \\
$N$ & $(-1.87)$ & $(-1.85)$ \\
Adjusted $R^{2}$ & Included & Included \\
& 2374 & 2374 \\
Panel B & 0.118 & 0.115 \\
\hline
\end{tabular}

Panel B. Changes to Industry Specialist Auditor

\begin{tabular}{ccccc}
\hline \multirow{2}{*}{ Variable } & \multicolumn{2}{c}{ ISPE1 } & \multicolumn{2}{c}{ ISPE2 } \\
\cline { 2 - 5 } & $\mathbf{( 1 )}$ & $\mathbf{( 2 )}$ & $\mathbf{( 1 )}$ & $\mathbf{( 2 )}$ \\
\hline Intercept & -2.996 & -3.032 & -3.372 & -3.381 \\
& $(-1.38)$ & $(-1.40)$ & $(-1.40)$ & $(-1.41)$ \\
UNION & $0.506^{* *}$ & & $0.471^{*}$ & \\
& $(2.17)$ & & $(1.89)$ & $0.850 *$ \\
UNIONRATE & & $0.878^{* *}$ & & $(1.93)$ \\
\hline
\end{tabular}


Table 8. Cont.

\begin{tabular}{ccccc}
\hline SIZE & 0.072 & 0.079 & 0.080 & 0.085 \\
& $(0.63)$ & $(0.69)$ & $(0.63)$ & $(0.67)$ \\
LOSS & $-0.666^{*}$ & $-0.662^{*}$ & $-0.784^{*}$ & $-0.779 *$ \\
& $(-1.71)$ & $(-1.72)$ & $(-1.89)$ & $(-1.91)$ \\
OCF & 1.583 & 1.525 & 0.708 & 0.628 \\
& $(1.08)$ & $(1.04)$ & $(0.44)$ & $(0.39)$ \\
ROA & -1.065 & -1.148 & -1.165 & -1.218 \\
& $(-0.59)$ & $(-0.63)$ & $(-0.57)$ & $(-0.59)$ \\
INVREC & 0.778 & 0.767 & 1.311 & 1.288 \\
CONSOL & $(1.02)$ & $(1.01)$ & $(1.60)$ & $(1.57)$ \\
& -0.269 & -0.294 & -0.081 & -0.105 \\
Industry, year dummy & $(-1.03)$ & $(-1.13)$ & $(-0.29)$ & $(-0.38)$ \\
\hline N & \multicolumn{2}{c}{ included } & included \\
\hline Pseudo R & 581 & 581 & 581 & 581 \\
& 0.040 & 0.039 & 0.043 & 0.043 \\
\hline
\end{tabular}

This table reports the main results using propensity score matching. Panel A reports the effect of labor unions (union power) on auditor tenure, and Panel B reports whether the firm changes its auditor to an industry specialist when a labor union exists or the power of the labor union increases. T-statistics (Z-statistics) are presented below the coefficient within parentheses. Standard errors are clustered by firm level. Coefficients and $\mathrm{t}$-statistics that are colored are directly related to our hypothesis. See Appendix A for the definitions of all variables. ${ }^{* * *}$, and ${ }^{* * *}$ indicate significance at the $10 \%, 5 \%$ and $1 \%$ levels, respectively.

\section{Conclusions}

This study investigates the association between labor unions or unionization rates and changes in external auditors. We posit that if a labor union has a strong demand for high-quality audits (in order to ensure a faithful representation of financial information in the collective bargaining process) and the firm reacts to this demand, the firm will change its external auditor more often, and the change will likely be to a high-quality auditor. The empirical results suggest that the presence and power of labor unions are negatively associated with external auditor tenure. This result indicates that labor unions are more likely to be concerned that a longer auditor tenure may deteriorate audit quality and affect firms' auditor selection process. We also find that when changing auditors, a firm with a labor union is more likely to move from a low-to a high-quality auditor (i.e., both a Big 4 and an industry specialist auditor). This result implies that labor unions exert pressure on a firm to select high-quality auditors if the firm was previously audited by a comparatively low-quality auditor.

This study extends the literature on the governance role of labor unions in auditor selection and audit quality setting. Our study suggests that labor unions play a positive monitoring role by reducing auditor tenure and demanding auditor changes to high-quality auditors, and therefore, the auditor tenure in companies with unions is decreased. By reducing auditor tenure, unions can secure the independence of the auditor, which results in a higher-quality audit. These results provide alternative and more convincing evidence and an additional explanation of the findings of previous research (Chung et al. [26]; Cheng et al. [35]) that companies with labor unions are generally audited by high-quality auditors. We expect that the results provide useful implications for investors to predict audit quality for firms with a labor union. Our study has limitations in that the sample does not cover recent periods due to public data availability and that the sample is from only one country. Thus, caution may be needed in applying the results to another country with different institutional and cultural background. However, our sample is unique and relevant for examining the role of labor unions because Korean labor unions are known as the strongest and most influential in the world. Future research can extend our study by examining the effect of interactions between labor unions and other governance mechanisms, such as audit committees and/or internal control characteristics, or firm characteristics, such as size, ownership or age, on audit quality. 
Author Contributions: The manuscript was written by E.J.C. and J.R.C. Both authors contributed to the study design and the results interpretation. H.-Y.L. supervised and revised the overall manuscript. All authors approved the final version.

Funding: This work was supported by the Ministry of Education of the Republic of Korea and the National Research Foundation of Korea (NRF-2018S1A5A8027760).

Conflicts of Interest: The authors declare no conflict of interest.

\section{Appendix A. Definition of Variables}

\begin{tabular}{llr}
\hline & & Dependent Variables \\
\hline Auditor Tenure & $=$ & Natural logarithm of audit tenure \\
\hline Auditor Change
\end{tabular}

\section{References}

1. Rodgers, W.; Guiral, A.; Gonzalo, J.A. Trusting/detrusting Auditors' Opinions. Sustainability 2019, 11, 1666. [CrossRef]

2. Jin, S.J.; Hwang, I.T.; Kang, S.M. Improving Sustainability Through a Dual Audit System. Sustainability 2018, 10, 137. [CrossRef]

3. Roumeen, I. Does More Transparency Go Along with Better Governance? Econ. Polit. 2006, 18, $121-167$.

4. Dhaliwal, D.; Li, O.Z.; Tsang, A.; Yang, Y.G. Corporate Social Responsibility Disclosure and The Cost of Equity Capital: The Roles of Stakeholder Orientation and Financial Transparency. J. Account. Public Policy 2014, 33, 328-355. [CrossRef]

5. Hyundai Motor, GM Noble. Available online: Unionhttp://www.skyedaily.com/news/news_view.html?ID= 75470 (accessed on 27 November 2018).

6. Connolly, R.A.; Hirsch, B.T.; Hirschey, M. Union Rent Seeking, Intangible Capital, and Market Value of the Firm. Rev. Econ. Stat. 1986, 68, 567-577. [CrossRef]

7. Kau, J.B.; Rubin, P.H. Voting on Minimum Wages: A Time-series Analysis. J. Polit. Econ. 1978, 86, 337-342. [CrossRef] 
8. Box-Steffensmeier, J.M.; Arnold, L.W.; Zorn, C.J.W. The Strategic Timing of Position Taking in Congress: A Study of the North American Free Trade Agreement. Am. Polit. Sci. Rev. 1997, 91, 324-338. [CrossRef]

9. Jansa, J.M.; Hoyman, M.M. Do Unions Punish Democrats? Free-Trade Votes and Labor PAC Contributions, 1999-2012. Polit. Res. Q. 2018, 71, 424-439. [CrossRef]

10. Becher, M.; Stegmuller, D.; Kappner, K. Local Union Organization and Law Making in the US Congress. J. Polit. 2018, 80, 539-554. [CrossRef]

11. Chyz, J.A.; Leung, W.S.C.; Li, O.Z.; Rui, O.M. Labor Unions and Tax Aggressiveness. J. Financ. Econ. 2013, 108, 675-698. [CrossRef]

12. Choi, J.; Bae, M. Effect of Labor Union on Earning Management. Korean Manag. Rev. 2011, 40, 1549-1575.

13. Kleiner, M.; Bouillon, M. Providing Business Information to Production Workers: Correlates of Compensation and Profitability. Ind. Labor Relat. Rev. 1988, 41, 605-617. [CrossRef]

14. Leung, W.; Li, O.; Rui, O. Labor Union and Accounting Conservatism. Working Paper. 2009. Available online: https://ssrn.com/abstract=1462594 (accessed on 27 November 2018). [CrossRef]

15. Appelbaum, E.; Hunter, L. Union Participation in Strategic Decisions of Corporations. Natl. Bur. Econ. Res. 2004, 265-292. [CrossRef]

16. Hilary, G. Organized Labor and Information Asymmetry in the Financial Markets. Rev. Account. Stud. 2006, 11, 525-548. [CrossRef]

17. Bova, F. Labor Unions and Management's Incentive to Signal a Negative Outlook. Contemp. Account. Res. 2013, 30, 14-41. [CrossRef]

18. Chung, J.R.; Cho, E.J.; Lee, H.Y.; Son, M. The Impact of Labor Unions on External Auditor Selection and Audit Scope: Evidence from the Korean Market. Appl. Econ. 2017, 49, 4833-4850. [CrossRef]

19. Cheng, L.; Mitra, S.; Song, H. Organized Labor and Audit Fees. Account. Horiz. 2017, 31, 93-108. [CrossRef]

20. Blouin, J.; Grein, B.M.; Rountree, B.R. An Analysis of Forced Auditor Change: The Case of Former Arthur Anderson Clients. Account. Rev. 2007, 82, 621-650. [CrossRef]

21. Chen, C.J.P.; Su, X.; Wu, X. Forced Audit Firm Change, Continued Partner-Client Relationship, and Financial Reporting Quality. Audit. J. Pract. Theory 2009, 28, 227-246. [CrossRef]

22. Catanach, A.H.; Walker, P.L. The International Debate Over Mandatory Auditor Rotation: A Conceptual Research Framework. J. Int. Account. Audit. Tax. 1999, 8, 43-66. [CrossRef]

23. O'Sullivan, N. The Impact of Board Composition and Ownership on Audit Quality: Evidence from Large UK Companies. Br. Account. Rev. 2000, 32, 397-414. [CrossRef]

24. Carcello, J.V.; Hermanson, D.R.; Neal, T.L.; Riley, R.A., Jr. Board characteristics and audit fees. Contemp. Account. Res. 2002, 19, 365-384. [CrossRef]

25. Carcello, J.V.; Neal, T.L. Audit Committee Characteristics and Auditor Dismissals following "New" Going-concern Reports. Account. Rev. 2003, 78, 95-117. [CrossRef]

26. Klein, A. Audit Committee, Board of Director Characteristics, and Earnings Management. J. Account. Econ. 2002, 33, 375-400. [CrossRef]

27. Lee, H.Y.; Mande, V.; Ortman, R. The Effect of Audit Committee and Board of Director Independence on Auditor Resignation. Audit. J. Pract. Theory. 2004, 23, 131-146. [CrossRef]

28. Beasley, M.S.; Petroni, K.R. Board Independence and Audit-Firm Type. Audit. J. Pract. Theory 2001, 20, 97-114. [CrossRef]

29. Carey, P.; Simnett, R. Audit Partner Tenure and Audit Quality. Account. Rev. 2006, 81, 653-676. [CrossRef]

30. Davis, L.R.; Soo, B.S.; Trompeter, G.M. Auditor Tenure and the Ability to Meet or Beat Earnings Forecasts. Contemp. Account. Res. 2009, 26, 517-548. [CrossRef]

31. Dopuch, N.; King, R.R.; Schwartz, R. An Experimental Investigation of Retention and Rotation Requirements. J. Account. Res. 2001, 39, 93-117. [CrossRef]

32. Jung, B.K. The Political Empowerment of Working Class of the KCTU and the Evaluation of It: Focused on its Understanding about Trade Union and Political Empowerment of Working Class and Its Relation with the DLP. Korean J. Labor Stud. 2016, 22, 75-101.

33. Chen, H.J.; Kacperczyk, M.; Ortiz-olina, H. Do non-Financial Stakeholders Affect the Pricing of Risky Debt? Evidence from Unionized Workers. Rev. Financ. 2012, 16, 347-383. [CrossRef]

34. Heish, H.Y.; Jung, B.; Yi, H. The Impact of Non-Financial Stakeholders on Accounting Conservatism: The Case of Labor Unions. Seoul J. Bus. 2017, 23, 1-37. 
35. Chung, R.; Lee, B.B.; Lee, W.J.; Sohn, B.C. Do Managers Withhold Good News from Labor Unions? Manag. Sci. 2016, 62, 46-68.

36. D'Souza, J.; Jacob, J.; Ramesh, K. The Use of Accounting Flexibility to Reduce Labor Renegotiation Costs and Manage Earnings. J. Account. Econ. 2001, 30, 187-208. [CrossRef]

37. DeAngelo, L. Auditor Size and Audit Quality. J. Account. Econ. 1981, 3, 183-199. [CrossRef]

38. Myers, J.N.; Myers, L.A.; Omer, T.C. Exploring the Term of the Auditor-Client Relationship and the Quality of Earnings: A Case for Mandatory Auditor Relation? Account. Rev. 2003, 78, 779-799. [CrossRef]

39. Geiger, M.A.; Raghunandan, K. Auditor Tenure and Audit Reporting Failures. Audit. J. Pract. Theory 2002, 21, 67-78. [CrossRef]

40. Johnson, V.E.; Khurana, I.K.; Reynolds, J.K. Audit-Firm Tenure and the Quality of Financial Reports. Contemp. Account. Res. 2002, 19, 637-660. [CrossRef]

41. Kealey, B.; Lee, H.Y.; Stein, M. The Association between Audit-Firm Tenure and Audit Fees Paid to Successor Auditors: Evidence from Arthur Andersen. Audit. J. Pract. Theory 2007, 26, 95-116. [CrossRef]

42. Smith, D.B. Auditor "Subject to" Opinions, Disclaimers, and Auditor Changes. Audit. J. Pract. Theory 1986, 6, 95-108.

43. Davidson, W.N., III; Jiraporn, P.; Dadalt, P. Causes and Consequences of Audit Shopping: An Analysis of Auditor Opinions, Earnings Managements, and Auditor Changes. Q. J. Bus. Econ. 2006, 45, 69-87. [CrossRef]

44. Francis, B.B.; Hunter, D.M.; Robinson, D.M.; Robinsion, M.N.; Yuan, X. Auditor Changes and the Cost of Bank Debt. Account. Rev. 2017, 92, 1-30. [CrossRef]

45. Robinson, D.R.; Owens-Jackson, L.A. Audit Committee Characteristics and Auditor Changes. Acad. Account. Financ. Stud. J. 2009, 13, 117-132.

46. Lee, S.; Rhee, M.; Yoon, J. Foreign Monitoring and Audit Quality: Evidence from Korea. Sustainability 2018, 10, 3151. [CrossRef]

47. Mande, V.; Son, M. Do Financial Restatements Lead to Auditor Changes? Audit. J. Pract. Theory 2013, 32, 119-145. [CrossRef]

48. Klasa, S.; Maxwell, W.; Ortiz-Molina, H. The Strategic Use of Corporate Cash Holdings in Collective Bargaining with Labor Unions. J. Financ. Econ. 2009, 92, 421-442. [CrossRef]

49. Matsa, D. Capital Structure as a Strategic Variable: Evidence from Collective Bargaining. J. Financ. 2010, 65, 1197-1232. [CrossRef]

50. Blanchflower, D.; Oswald, G.A.; Sanfey, P. Wages, Profits, and Rent-Sharing. Q. J. Econ. 1996, 111, $227-251$. [CrossRef]

51. DeAngelo, H.; DeAngelo, L. Union Negotiations and Corporate Policy: A Study of Labor Concessions in the Domestic Steel Industry during the 1980s. J. Financ. Econ. 1991, 30, 3-43. [CrossRef]

52. Mora, A.; Sabater, A. Evidence of Income-Decreasing Earnings Management before Labor Negotiations with the Firms. Investig. Econ. 2008, 32, 201-230.

53. Lee, H.I. The Effect of Auditor Change on Audit opinion- Focusing on Auditor Independence under the Free Appointment Regulation of External Auditor. Korean Account. Rev 1990, 11, 181-218.

54. Leap, T.L.; Hendrix, W.H.; Cantrell, R.S.; Taylor, G.S. Discrimination against pro-Union Job Applicants. J. Econ. Soc. 1990, 29, 469-478.

55. Kohlbeck, M.; Mayhew, B.W. Are Related Party Transactions Red Flags? Contemp. Account. Res. 2017, 34, 900-928. [CrossRef]

56. Deis, D.R., Jr.; Giroux, G.A. Determinants of Audit Quality in the Public Sector. Account. Rev. 1992, 67, 462-479.

57. Balsam, S.; Krishnan, J.; Yang, J. Auditor Industry Specialization and Earning Quality. Audit. J. Pract. Theory. 2003, 22, 71-97. [CrossRef]

58. Krishnan, G.V. Does Big 6 Auditor Industry Expertise Constrain Earnings Management? Account. Horiz. 2003, 17, 1-16. [CrossRef]

59. Carcello, J.V.; Nagy, A.L. Client Size, Auditor Specialization and Fraudulent Financial Reporting. Manag. Audit. J. 2004, 19, 651-668. [CrossRef]

60. Reichelt, K.J.; Wang, D. National and Office-Specific Measures of Auditor Industry Expertise and Effects on Audit Quality. J. Account. Res. 2010, 48, 647-686. [CrossRef]

61. DeBoskey, D.G.; Jiang, W. Earnings Management and Auditor Specialization in the Post-SOX Era: An Examination of the Banking Industry. J. Bank. Financ. 2012, 36, 613-623. [CrossRef] 
62. Knechel, W.R.; Naiker, V.; Pacheco, G. Does Auditor Industry Specialization Matter? Evidence from Market Reaction to Auditor Switches. Audit. J. Pract. Theory 2007, 26, 19-45. [CrossRef]

63. Craswell, A.; Taylor, S.L. The Market Structure of Auditing in Australia: The Role of Industry Specialization. Res. Account. Regul. 1991, 5, 55-77.

64. DeFond, M.L.; Francis, J.R.; Wong, T.J. Auditor Industry Specialization and Market Segmentation: Evidence from Hong Kong. Audit. J. Pract. Theory 2010, 19, 49-66. [CrossRef]

65. Ferguson, A.; Stokes, D. Brand Name Audit Pricing, Industry Specialization, and Leadership Premium Post-Big 8 and Big 6 Mergers. Contemp. Account. Res. 2002, 19, 77-110. [CrossRef]

66. Craswell, A.; Francis, J.; Taylor, S.L. Auditor Brand Name Reputation and Industry Specialization. J. Account. Econ. 1995, 20, 297-322. [CrossRef]

67. Choi, J.; Wong, T. Auditors' Governance Functions and Legal Environments: An International Investigation. Contemp. Account. Res. 2007, 24, 13-46. [CrossRef]

68. Simunic, D.; Stein, M. Product Differentiation in Auditing: A Study of Auditor Choice in the Market for Unseasoned New Issues; The Canadian Certified General Accountants' Research Foundation: Vancouver, BC, Canada, 1987.

69. Pierre, K.S.; Anderson, J.A. An Analysis of the Factors Associated with Lawsuits against Public Accountants. Account. Rev. 1984, 59, 242-263.

70. Hope, O.; Kang, T.; Thomas, W.; Yoo, Y. Culture and Auditor Choice: A Test of the Secrecy Hypothesis. J. Account. Public Policy 2007, 27, 357-373. [CrossRef]

71. Bronars, S.G.; Deere, D.R. The Threat of Unionization, the Use of Debt and the Preservation of Shareholder Wealth. Q. J. Econ. 1991, 106, 231-254. [CrossRef]

72. Becker, C.; DeFond, M.; Jiambalvo, J.; Subramanyam, K.R. The Effect of Audit Quality on Earnings Management. Contemp. Account. Res. 1998, 15, 1-24. [CrossRef]

73. Lawrence, A.; Minutti-Meza, M.; Zhang, P. Can Big 4 versus Non-Big 4 differences in Audit-Quality Proxies Be Attributed to Client Characteristics? Account. Rev. 2011, 86, 259-286. [CrossRef]

74. Eshleman, J.D.; Guo, P. Do Big 4 Auditors Provide Higher Audit Quality after Controlling for the Endogenous Choice of Auditor? Audit. J. Pract. Theory 2014, 33, 197-219. [CrossRef]

75. Dopuch, N.; Simunic, D. Competition in Auditing: An Assessment. In Forth Symposium on Auditing Research; University of Illinois: Urbana, IL, USA, 1982; Volume 401, p. 50.

76. Minutti-Meza, M. Does Auditor Industry Specialization Improve Audit Quality? J. Account. Res. 2013, 51, 779-817. [CrossRef] 